\title{
The classification of insect communities: Lessons from orthopteran assemblages of semi-dry calcareous grasslands in central Germany
}

\author{
DOMINIK PONIATOWSKI and THOMAS FARTMANN*
} Department of Community Ecology, Institute of Landscape Ecology, University of Münster, Robert-Koch-Straße 26,
48149 Münster, Germany

Key words. Orthoptera, community completeness, community ecology, Europe, grasshopper, habitat requirements, habitat structure

\begin{abstract}
Whereas the classification of plant communities has a long tradition that of animal assemblages remains poorly developed. Here we propose a classification scheme for orthopteran communities based on regional "character species", "differential species" and "attendant species" at different levels of habitat complexity, which is also applicable to other insect groups. In this context there are three main points of special importance: (i) the geographical reference area, (ii) the hierarchical spatial level (e.g. habitat complex, habitat and microhabitat) and (iii) precise constancy criteria for the definition of character species and differential species. We develop this new approach using a study on orthopteran communites of central German semi-dry calcareous grasslands. Within this habitat, we describe seven structural types that are characterized by specific orthopteran communities. For the arrangement of the structural types several environmental parameters (e.g. height and density of vegetation) were collected. Orthopteran densities were sampled at 80 sites using a biocoenometer (box quadrat). Regional character species of semi-dry grasslands include Myrmeleotettix maculatus, Metrioptera brachyptera, Stenobothrus lineatus and Tetrix tenuicornis. Within this habitat, Chorthippus parallelus, Metrioptera roeselii, Omocestus viridulus, Pholidoptera griseoaptera and Tettigonia viridissima were designated as differential species for particular structural types. Furthermore, Tettigonia cantans and Tettigonia viridissima act as altitudinal differential species. Chorthippus biguttulus is the only attendant species with high constancy values in all structural types. This classification is a powerful tool for arthropod conservation, since it allows one to determine community completeness of very important and threatened habitats, like semi-dry calcareous grasslands.
\end{abstract}

\section{INTRODUCTION}

A major goal of synecology is to analyse the composition and structure of plant and animal communities. The composition of plant communities attracted considerable interest during the past century, leading to the development of various global and regional classification approaches. In central Europe, vegetation synecology is dominated by the floristic-sociological or Braun-Blanquet (Zürich-Montpellier) approach (Mucina, 1997). As a basic principle, this approach classifies communities by the absence or presence of species with highly specific ecological niches, so called diagnostic species. Identification of diagnostic species is based on the constancy (fidelity) with which they occur in an array of plots that share important abiotic and biotic conditions. Nowadays, classification rules for plant communities allow highly differentiated characterizations of local ecological conditions (Bruelheide, 2000; Chytrý et al., 2002; Dengler, 2003).

There are no comparable standards for the characterization of terrestrial animal communities. Recently, some studies in central Europe attempted to make the classification of animal communities more transparent. Similar to phytosociology, they defined character species and differential species based on their fidelity to study plots with shared environmental conditions as the two diagnostic groups (Seitz, 1989; Flade, 1994; Fartmann, 1997; Schultz \& Finch, 1997; Behrens \& Fartmann, 2004a).
However, the definitions of the diagnostic species in these studies were arbitrary. A unified classification system also needs to take into account at which spatial level animal communities are studied. Studies on animal communities typically occur at three spatial levels: (i) the level of habitat complexes or plant-community complexes, often coinciding with a landscape-level approach; (ii) the level of single habitats or single plantcommunities; and (iii) the level of structural habitat composition, which may vary within a habitat or plant community (Kratochwil \& Schwabe, 2001). Here we develop a method for the assignment of regional character, differential and attendant species to structural types that is applicable to a wide array of other insect groups and other hierarchical levels.

Habitat selection in Orthoptera is the result of their responding to a complex combination of different and often interrelated environmental factors (see review in Ingrisch \& Köhler, 1998). Within these parameters, the microclimate at oviposition sites, which is often affected by vegetation structure, plays a crucial role (Oschmann, 1973; Uvarov, 1977; Anderson et al., 1979; Willott \& Hassall, 1998). As cold-blooded organisms, most Orthoptera require high ambient temperatures for optimal growth and development (Chappell \& Whitman, 1990). Because of their high diversity, functional importance and sensitivity to environmental change (Báldi \& Kisbenedek,

\footnotetext{
* Corresponding author; e-mail: fartmann@uni-muenster.de
} 


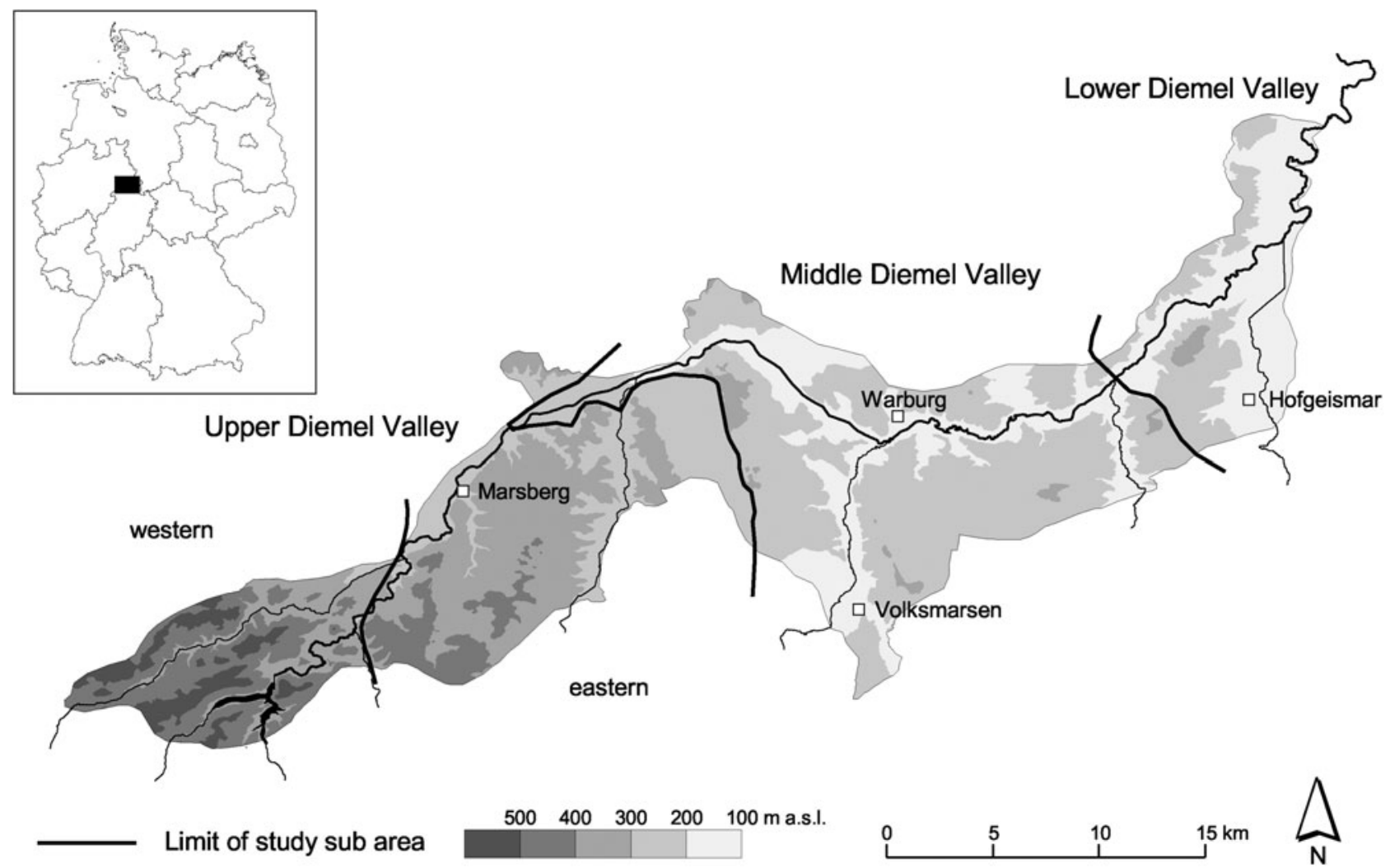

Fig. 1. The study area; the Diemel Valley and its sub areas in northwestern Germany (inlay).

1997; Samways, 1997; Andersen et al., 2001; Szövényi, 2002; Bieringer \& Zulka, 2003), we expect Orthoptera to be highly indicative of grassland characteristics. The relatively good knowledge of their taxonomy and distribution as well as the ease with which they can be sampled make Orthoptera suitable subjects for ecological and biogeographical community studies (Sergeev, 1997; Lockwood \& Sergeev, 2000). In recent decades, there have been several studies on orthopteran assemblages in the northern hemisphere; especially in North America, where different aspects of rangeland grasshopper communities have been studied in detail (e.g. Kemp et al., 1990; Kemp 1992a, b; Fielding \& Brusven, 1993; 1995; Joern, 2004, 2005; Jonas \& Joern, 2007). Most of the community studies done in the Palaearctic are for central Europe and address dry and semi-dry grassland habitats (e.g. Sänger, 1977; Fartmann, 1997; Zehm, 1997; Hemp \& Hemp, 2000; Behrens \& Fartmann, 2004a).

The current study was conducted in semi-dry calcareous grasslands in the Diemel Valley (central Germany). Despite a recent decrease in area, the size of these calcareous grasslands in Germany is only matched by some regions in the south (Fartmann, 2004, 2006). An important attribute of these semi-natural habitats is their structural and floristic diversity and species-rich fauna (WallisDeVries et al., 2002; van Swaay, 2002; Fartmann, 2004). Thus, these open habitats are important for many orthopteran species (Detzel, 1998; Schlumprecht, 2003). Due to their importance calcareous grasslands are listed in the Habitats Directive of the European Union and the orchid-rich stands are priority habitats (Ssymank et al., 1998).

A biogeographic study on the grasshopper and cricket fauna of the semi-dry grasslands of the Diemel Valley was recently published by Poniatowski \& Fartmann (2006). However, there is no description of the orthopteran communities of the largest continuous area of calcareous grassland in Northwest Germany. Therefore, the objective of this investigation of the orthopteran communities in the semi-dry calcareous grasslands of the Diemel Valley was to (i) investigate orthopteran species composition of sites that are broadly similar in plant community but differ in vegetation structure, (ii) define character and differential species for the classification of the communities, (iii) analyse orthopteran habitat requirements in relation to habitat structure and microclimate.

\section{MATERIAL AND METHODS}

\section{Study area}

The study area (hereafter called Diemel Valley) of about 500 $\mathrm{km}^{2}$ is located in central Germany along the border between the federal states of North Rhine-Westphalia and Hesse $\left(51^{\circ} 22^{\prime} \mathrm{N} / 8^{\circ} 38^{\prime} \mathrm{E}\right.$ and $\left.51^{\circ} 38^{\prime} \mathrm{N} / 9^{\circ} 25^{\prime} \mathrm{E}\right)$ at an elevation of 160 to $480 \mathrm{~m}$ a.s.l. (Fig. 1). The climate is subatlantic and varies greatly according to altitude (Müller-Wille, 1981). The Upper Diemel Valley (300-500 $\mathrm{m}$ a.s.l.) is the coldest and wettest section with mean temperatures of $6.5-8^{\circ} \mathrm{C}$ and an annual precipitation of $700-1,000 \mathrm{~mm}$ (Table 1). The Middle and Lower Diemel Valley $(<300 \mathrm{~m}$ a.s.l.) in the eastern part of the study area have a relatively mild climate with less than $800 \mathrm{~mm}$ annual precipitation and an average annual temperature of up to 
TABLE 1. Characteristic environmental factors of sub areas of the Diemel Valley (modified after Fartmann, 2004).

\begin{tabular}{|c|c|c|c|c|}
\hline & \multicolumn{4}{|c|}{ Diemel Valley } \\
\hline & \multicolumn{2}{|r|}{ Upper } & \multirow{2}{*}{ Middle } & \multirow{2}{*}{ Lower } \\
\hline & Western & Eastern & & \\
\hline Biogeographic region & $\begin{array}{l}\text { Bergisch-Sauer- } \\
\text { ländisches Gebirge }\end{array}$ & $\begin{array}{l}\text { Bergisch-Sauerländisches } \\
\text { Gebirge, Hessisches Berg- } \\
\text { and Senkenland }\end{array}$ & $\begin{array}{l}\text { Hessisches Berg- and } \\
\text { Senkenland, Oberes } \\
\text { Weserbergland }\end{array}$ & $\begin{array}{l}\text { Hessisches Berg- and } \\
\text { Senkenland, Oberes } \\
\text { Weserbergland }\end{array}$ \\
\hline Bedrock & $\begin{array}{l}\text { Shale, quartzite and } \\
\text { diabas }\end{array}$ & $\begin{array}{l}\text { Zechstein limestone and } \\
\text { brownstone }\end{array}$ & $\begin{array}{l}\text { Shell limestone, keuper } \\
\text { and loess }\end{array}$ & $\begin{array}{l}\text { Shell limestone, brown- } \\
\text { stone and fluviatile sedi- } \\
\text { ments }\end{array}$ \\
\hline Soil & $\begin{array}{l}\text { Base-rich brown earth } \\
\text { and ranker brown earth }\end{array}$ & $\begin{array}{l}\text { Rendzina, base-rich and } \\
\text { base-poor brown earth }\end{array}$ & Rendzina and lessivé & Rendzina and lessivé \\
\hline Altitude (m a.s.l.) & $400-500$ & $300-400$ & $200-300$ & $100-200$ \\
\hline Annual precipitation (mm) & $850-1,000$ & $700-850$ & $600-800$ & $650-800$ \\
\hline Annual temperature $\left({ }^{\circ} \mathrm{C}\right)$ & $6.5-8$ & $7.5-8$ & $8-8.5$ & $7.5-9$ \\
\hline
\end{tabular}

$9^{\circ} \mathrm{C}$ (Müller-Temme, 1986; MURL NRW, 1989; Fartmann, 2004).

For a detailed description of the study sites see Poniatowski (2006). Further information on geology, soils, climate, vegetation and nature conservation is available in Fartmann (2004, 2006).

\section{Study design}

A total of 80 plots at 26 sites on calcareous soils were analysed in order to characterize orthopteran communities of the semi-dry grasslands of the Diemel Valley. For each plot, we recorded the following environmental parameters (Table 2).

\section{Climate}

Aspect and slope of the plots were recorded by using a compass with an inclinometer. Maximal average sunshine duration for August was determined using a horizontoscope (Tonne, 1954).

\section{Plant communities}

For assessing the plant community at each plot a mapping key was prepared, based on character and differential species and/or dominant species (Dierschke, 1994). Fartmann (2004) acted as a phytosociological reference. Nomenclature of plant species and plant communities follow Wisskirchen \& Haeupler (1998) and Rennwald (2000), respectively.

Vegetation structure

All study plots, each with a minimum size of $500 \mathrm{~m}^{2}$ (e.g. Behrens \& Fartmann, 2004a; Poniatowski \& Fartmann, 2005), had a homogenous vegetation structure (Sänger, 1977). This means that the vegetation height, density and cover were more or less uniform. The measurement of structural parameters took place after the quantitative sampling of Orthoptera (see below) in an undisturbed section of the plot. Based on these structural parameters, plots with a similar structure were grouped in structural types (e.g. Fartmann, 1997; Behrens \& Fartmann, 2004a; Poniatowski \& Fartmann, 2005) (see below, data analysis).

Horizontal structure: We recorded (in 5\% steps) total vegetation cover, the cover of litter, mosses/lichens, grasses/herbs, shrubs as well as bare ground, gravel, stones and rocks. In cases where cover was above $95 \%$ or below $5 \%$, according to Behrens \& Fartmann (2004a) 2.5\% steps were used.

Vertical structure: The average vegetation height, the vegetation layer with the highest solar-irradiation conversion, was ascertained with an accuracy of $2.5 \mathrm{~cm}$. Horizontal vegetation density (Sundermeier, 1998) was estimated using a $50 \mathrm{~cm}$ wide and $30 \mathrm{~cm}$ deep wire framed box (Mühlenberg, 1993), which was open on all sites except the back. Horizontal wires on the

TABLE 2. The parameters used in the Detrended Correspondence Analysis (DCA) and structural type (st) characterization.

\begin{tabular}{|c|c|c|}
\hline & Type & Study part \\
\hline \multicolumn{3}{|l|}{ Climate } \\
\hline Aspect (“eastness”, “northness”)1 & $\left({ }^{\circ}\right)$ & DCA* \\
\hline Inclination & $\left({ }^{\circ}\right)$ & $\mathrm{DCA}^{*}$ \\
\hline Potential daily sunshine duration ${ }^{2}$ & (h) & DCA \\
\hline Altitude & (m a.s.1.) & DCA \\
\hline \multicolumn{3}{|l|}{ Vegetation structure } \\
\hline Cover of different layers ${ }^{3}$ & $(\%)$ & $\mathrm{DCA}^{* *}, \mathrm{st}$ \\
\hline Vegetation height & $(\mathrm{cm})$ & $\mathrm{DCA}^{*}, \mathrm{st}$ \\
\hline Horizontal vegetation density ${ }^{4}$ & $(\%)$ & DCA, st \\
\hline \multicolumn{3}{|l|}{ Habitat characteristics } \\
\hline Vegetation type & nominal & st \\
\hline
\end{tabular}




\section{Character and differential species model}

\section{Differential species criterion}

Following Dengler \& Berg (2004), a species achieves the differential species criterion if it has at least twice the constancy in one habitat/structural type compared to any other unit of the same hierarchical level. Furthermore, following Schmitt \& Fartmann (2006), a character/differential species must at least have a constancy of $20 \%$ in its typical unit $30 \%$ if the number of plots per unit is below 15). The maximum constancy in the compared units has to be $30 \%$.

\section{Hierarchical level: Habitat type}

Differential species criterion

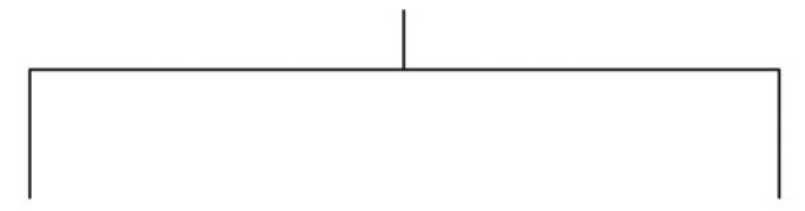

achieved

Character species not achieved

No character species

\section{Hierarchical level: Structural type}

Differential species criterion

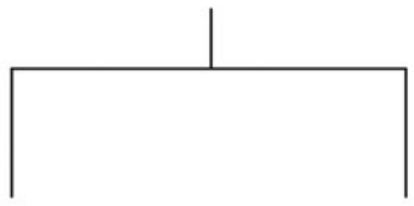

achieved

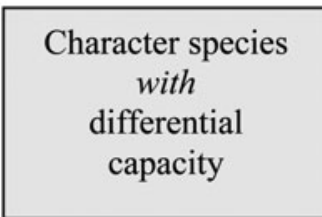

not achieved

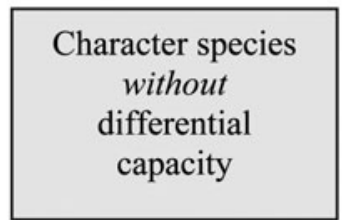

Differential species criterion

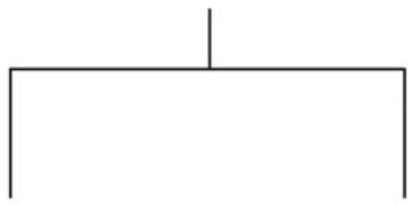

achieved

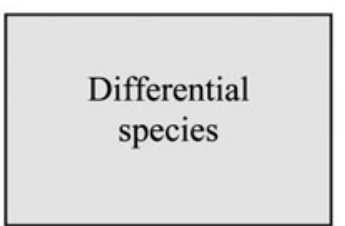

not achieved

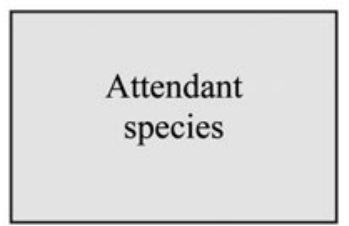

Fig. 2. Character and differential species for the classification of insect communities.

front side of the box divided it into six layers $(0-5,5-10$, etc. up to $25-30 \mathrm{~cm}$ ). The cover of each layer was horizontally viewed (the reciprocal value is the horizontal vegetation density) against the bright back of the box, using same classes as for the horizontal structure.

Orthopteran sampling

For orthopteran sampling every plot was visited twice: The first survey (between the end of April and beginning of June) was used to detect tetrigids, which reach their population peaks during this period (Fartmann, 1997). For this purpose the sites with bare ground were searched visually. Quantitative sampling of all orthopteran species in open habitats took place during mid-July and the beginning of August. Orthopteran densities were recorded using a biocoenometer (box quadrat) with sides of $0.8 \mathrm{~m}$ (Behrens \& Fartmann, 2004a; Gardiner et al., 2005; Poniatowski \& Fartmann, 2005; Fartmann et al., 2008). The mobile $0.5 \mathrm{~m}^{2}$ box quadrat was randomly placed at forty different points per plot $\left(=20 \mathrm{~m}^{2}\right.$ surveyed area per plot). 
Orthoptera species were identified in the field and then released. Species, sex and stage (nymph or imago) were noted for all specimens. Adults were identified using Bellmann (1993) and Horstkotte et al. (1994), for nymphs we used Oschmann (1969) and Ingrisch (1977). Identification of nymphs of the sibling species Chorthippus biguttulus and C. brunneus was not possible. They were merged in the C. bigutullus group. Due to the rarity of $C$. brunneus in the semi-dry grasslands of the study area (Poniatowski \& Fartmann, 2006), nearly all nymphs of the group are likely to belong to $C$. biguttulus. Tetrigids (adults and nymphs) were identified using the key in Schulte (2003). Scientific nomenclature followed Coray \& Lehmann (1998).

\section{Data analysis}

Plots with similar vegetation structure (structural types) were classified using Ward's method of agglomerative clustering based on Euclidean distance (Bacher, 1994; Jongman et al., 1995). Eight variables were imported to the statistical package SPSS 11.0: Total vegetation cover, cover of the field layer, cover of gravel, stones and rocks (from now on called stony surface), cover of bare ground, height of the field layer and horizontal vegetation density at three heights $(0-5 \mathrm{~cm}, 5-10 \mathrm{~cm}$ and $10-15 \mathrm{~cm}$ ). Prior to the analysis values were $\mathrm{z}$-tranformed.

Classification of orthopteran communities follows a method that is based on the assignment of character and/or differential species to a habitat (here: semi-dry calcareous grasslands) and every structural type within this habitat (Fig. 2). The validity of every diagnostic species is restricted to distinct biogeographical regions (here: the Diemel Valley). Furthermore, the method can be used for the determination of altitudinal differential species.

As the basic unit for the evaluation of character and differential species we use the differential species criterion after Dengler \& Berg (2004) with additions by Schmitt \& Fartmann (2006) (Fig. 2). The basis for this is the percentage constancy of the species in a habitat or structural type (calculated using the results of the quantitative orthopteran sampling). For the identification of character and differential species we take into account that the different developmental stages (nymphs, adults) have different phenologies. Thus, only one of the stages has to fulfil the differential species criterion.

There are generally two hierarchical levels:

\section{Habitat type}

First, we check at the level of a biogeographic region, if a species is restricted to a single habitat (regional character species) or occurs in several distinct habitats (not a character species) (for exact constancy definitions see Fig. 2). This evaluation requires knowledge of the constancy values of this species in all potentially suitable habitats (Seitz, 1989). Community studies rarely provide both the constancy of species in an array of habitats and different structural types within each habitat. However, the large-scale relationship between a certain species and habitats are much better documented than the preferences for structures within each habitat. Because of the lack of constancy values at the habitat level we classified character species on the basis of information in the literature (for the study area and its vicinity: Ingrisch, 1981, 1982; Schulte, 1997, 2003; Hill \& Beinlich, 2001; Poniatowski \& Fartmann, 2005, 2006, 2007).

\section{Structural types}

This step analyses the orthopteran communities in different structural types within a habitat (here: semi-dry calcareous grassland) (for the classification of the structural type see above). If a species meets the differential species criterion (see above) it is classified - depending on the initial position (character species or not) $-\mathrm{a}$ "character species with differential capacity" or a "differential species" (Fig. 2). In both cases, the species indicates certain qualities of the structural types (e.g. high vegetation cover). A differential species, unlike a character species with differential capacity, can also be found in other habitats in a particular biogeographic region. If the differential species criterion does not apply, the considered species is depending on the initial position (character species or not) either a "character species without differential capacity" or an "attendant species" (Fig. 2). The latter shows no preference for certain structural types, this means that the constancy is high in all structural types or the species is generally very rare (Fartmann, 1997).

Besides the presence of a species (here constancy), the dominance within a community is a further criterion of the suitability of a structural type for the species (Ingrisch \& Köhler, 1998). Thus, for every structure the dominance of every species was calculated and classified according to the dominance classes of Engelmann (1978) (eudominant $\geq 32 \%$, dominant = $10.0-31.9 \%$, subdominant $=3.2-9.9 \%$ ).

Detrended Correspondence Analysis (DCA) (using CANOCO 4.51; Hill, 1979; Hill \& Gauch, 1980; ter Braak \& Šmilauer, 2002), an indirect gradient ordination technique, was used to examine orthopteran community trends and relations between habitat structure and species composition (Fielding \& Brusven, 1993, 1995; Torrusio et al., 2002; Gebeyehu \& Samways, 2003, 2006). DCA is commonly used in vegetation and community ecology (Kratochwil \& Schwabe, 2001) and requires a unimodal distribution of the species. The following adjustments were carried out: Detrending by segments, no transformation.

\section{RESULTS}

\section{Orthopteran communities and structural types}

Based on the structural parameters the 80 plots could be placed in one of seven structural types characterized by increasing vegetation height and density (= productivity and biomass gradient) from type 1 to type 7 (Table 3 ). Each structural type was characterized by a specific set of character species, differential species and attendant species and thus a specific orthopteran community.

Information in the literature (e.g. Ingrisch, 1981; Schulte, 1997, 2003; Poniatowski \& Fartmann, 2006) indicates, that four species fulfill the criterion of a regional character species for the semi-dry calcareous grasslands in the Diemel Valley: Myrmeleotettix maculatus, Tetrix tenuicornis, Stenobothrus lineatus and Metrioptera brachyptera.

The findings of the current study show that Chorthippus parallelus, Pholidoptera griseoaptera, Omocestus viridulus, Metrioptera roeselii and Tettigonia viridissima are differential species for some structural types. Furthermore, Tettigonia viridissima and T. cantans, which are allopatric in the study area (Poniatowski \& Fartmann, 2006), are altitudinal differential species. T. cantans was present at all sites studied $(N=4)$ in the western Upper Diemel Valley and absent from the sites in the other three subareas. In contrast, there was an increase in the constancy of $T$. viridissima with decrease in altitude: western Upper Diemel Valley $(25 \%, N=4)$, eastern Upper Diemel Valley $(60 \%, N=5)$, Middle Diemel Valley $(86 \%, N=7)$ and Lower Diemel Valley $(80 \%, N=10)$. Among the ten attendant species, Chorthippus biguttulus 
TABLE 3. The orthopteran assemblages of the semi-dry calcareous grasslands in the Diemel Valley. Constancy table for seven structural types (plant communities and land-use, see text); percentage constancy values are given; classification of character species (CS) and differential species (DS) based on the differential species criterion (Fig. 2); Ny $=$ Nymphs, Im = Imago; superscript: range in the number of Orthoptera individuals $/ 20 \mathrm{~m}^{2}: \mathrm{q}=$ qualitative detection, $\mathrm{r}=1$ individual (ind.), $+=2-5$ ind., $1=6-10$ ind., $2=11-20$ ind., $3=21-50$ ind., 4 $=51-100$ ind., $5>100$ ind.; if not stated otherwise the values are medians; for further explanation see text.

\begin{tabular}{|c|c|c|c|c|c|c|c|}
\hline Structural type & 1 & 2 & 3 & 4 & 5 & 6 & 7 \\
\hline$N$ Study plots & 5 & 8 & 18 & 8 & 11 & 21 & 9 \\
\hline \multicolumn{8}{|l|}{ Median cover $(\%)$} \\
\hline Total vegetation & 40 & 75 & 90 & 85 & 95 & 95 & 100 \\
\hline Field layer & 40 & 70 & 80 & 80 & 90 & 90 & 95 \\
\hline Cryptogam layer & 3 & 13 & 23 & 5 & 15 & 50 & 0 \\
\hline Litter layer & 5 & 5 & 5 & 10 & 25 & 40 & 90 \\
\hline Bare ground & 30 & 18 & 5 & 13 & 3 & 0 & 0 \\
\hline Stony surface (= gravel, stones and rocks) & 30 & 9 & 0 & 1 & 0 & 0 & 0 \\
\hline Median vegetation height $(\mathrm{cm})$ & 2.5 & 5 & 5 & 10 & 10 & 20 & 30 \\
\hline \multicolumn{8}{|l|}{ Median horizontal vegetation density (\%) } \\
\hline $0-5 \mathrm{~cm}$ & 20 & 95 & 96 & 100 & 100 & 100 & 100 \\
\hline $5-10 \mathrm{~cm}$ & 3 & 5 & 10 & 70 & 95 & 98 & 100 \\
\hline $10-15 \mathrm{~cm}$ & 3 & 3 & 3 & 4 & 20 & 80 & 100 \\
\hline $15-20 \mathrm{~cm}$ & 0 & 0 & 3 & 3 & 5 & 20 & 95 \\
\hline $20-25 \mathrm{~cm}$ & 0 & 0 & 0 & 3 & 3 & 3 & 90 \\
\hline $25-30 \mathrm{~cm}$ & 0 & 0 & 0 & 0 & 0 & 3 & 70 \\
\hline Nymphs $/ 20 \mathrm{~m}^{2}$ & 19 & 14 & 25 & 23 & 31 & 24 & 7 \\
\hline Adults $/ 20 \mathrm{~m}^{2}$ & 16 & 10 & 11 & 22 & 17 & 23 & 15 \\
\hline Species number per plot (median and range) & $4^{2-4}$ & $3^{1-5}$ & $3^{2-5}$ & $4.5^{4-9}$ & $4^{2-6}$ & $5^{3-8}$ & $4^{3-8}$ \\
\hline Total species number & 4 & 7 & 8 & 11 & 10 & 16 & 13 \\
\hline \multicolumn{8}{|l|}{ CS of gravel-rich grassland } \\
\hline Myrmeleotettix maculatus Im & $80^{r-1}$ & · & . & $13^{\mathrm{r}}$ & . & . & $\cdot$ \\
\hline Myrmeleotettix maculatus $\mathrm{Ny}$ & $20^{\mathrm{r}}$ & . & . & $\cdot$ & . & . & . \\
\hline \multicolumn{8}{|l|}{ CS of gap-rich semi-dry grassland } \\
\hline Tetrix tenuicornis Im & $100^{q-2}$ & $88^{q-1}$ & $28^{\mathrm{q}-+}$ & $75^{q-1}$ & $27^{\mathrm{q}-\mathrm{r}}$ & $10^{\mathrm{r}}$ & . \\
\hline Tetrix tenuicornis $\mathrm{Ny}$ & $60^{q-+}$ & $75^{\mathrm{q}-+}$ & $22^{q-r}$ & $75^{\mathrm{q}-+}$ & $\cdot$ & $\cdot$ & . \\
\hline \multicolumn{8}{|l|}{ CS of low-growing semi-dry grassland } \\
\hline Stenobothrus lineatus Im & $60^{\mathrm{r}-+}$ & $88^{+-2}$ & $94^{\mathrm{q}-1}$ & $100^{\mathrm{r}-3}$ & $91^{q-2}$ & $57^{q-3}$ & $11^{\mathrm{q}}$ \\
\hline Stenobothrus lineatus $\mathrm{Ny}$ & $60^{\mathrm{r}-+}$ & $50^{\mathrm{r}-+}$ & $61^{\mathrm{r}-2}$ & $38^{\mathrm{r}-+}$ & $64^{\mathrm{r}-+}$ & $33^{\mathrm{r}-1}$ & $11^{+}$ \\
\hline \multicolumn{8}{|c|}{ DS of semi-dry grassland with high vegetation cover } \\
\hline Chorthippus parallelus Im & . & $13^{+}$ & $44^{\mathrm{q}-+}$ & $63^{\mathrm{r}-1}$ & $64^{q-3}$ & $71^{r-3}$ & $89^{+-3}$ \\
\hline Chorthippus parallelus $\mathrm{Ny}$ & . & $\cdot$ & $11^{1}$ & $13^{+}$ & $27^{\mathrm{r}-3}$ & $57^{\mathrm{r}-3}$ & $78^{+-3}$ \\
\hline \multicolumn{8}{|l|}{ CS of semi-dry grassland with little or no land use } \\
\hline Metrioptera brachyptera Im & . & $\cdot$ & $6^{\mathrm{r}}$ & $63^{q-3}$ & $36^{\mathrm{r}-1}$ & $95^{q-3}$ & $67^{\mathrm{r}-+}$ \\
\hline Metrioptera brachyptera $\mathrm{Ny}$ & . & . & . & $25^{\mathrm{r}-+}$ & $9^{r}$ & $52^{q-1}$ & $11^{\mathrm{r}}$ \\
\hline \multicolumn{8}{|c|}{ DS of semi-dry grassland with very little or no land use } \\
\hline Pholidoptera griseoaptera Im & . & $13^{\mathrm{r}}$ & . & $25^{+}$ & $18^{\mathrm{r}-+}$ & $52^{q-1}$ & $67^{q-1}$ \\
\hline Pholidoptera griseoaptera $\mathrm{Ny}$ & . & $\cdot$ & . & $13^{\mathrm{q}}$ & $9^{r}$ & $33^{r-+}$ & \\
\hline \multicolumn{8}{|c|}{ DS of medium- to high-growing semi-dry grassland at high altitude } \\
\hline Omocestus viridulus Im & . & $\cdot$ & . & . & $9^{+}$ & $52^{q-2}$ & $44^{\mathrm{r}-1}$ \\
\hline Omocestus viridulus $\mathrm{Ny}$ & . & . & $\cdot$ & . & $9^{r}$ & & \\
\hline \multicolumn{8}{|l|}{ DS of high-growing and dense semi-dry grassland } \\
\hline Metrioptera roeselii $\mathrm{Im}$ & . & . & . & $13^{\mathrm{r}}$ & . & $14^{\mathrm{q}-+}$ & $56^{\mathrm{q}-2}$ \\
\hline \multicolumn{8}{|l|}{ Altitudinal DS of semi-dry grassland } \\
\hline Lower to eastern Upper Diemel Valley & & & & & & & \\
\hline Tettigonia viridissima Im & . & . & . & $\cdot$ & $9^{+}$ & $14^{\mathrm{r}-+}$ & $33^{q-r}$ \\
\hline Tettigonia viridissima $\mathrm{Ny}$ & . & . & . & $13^{\mathrm{q}}$ & $18^{\mathrm{q}}$ & $\cdot$ & $11^{\mathrm{q}}$ \\
\hline western Upper Diemel Valley & & & & & & & \\
\hline Tettigonia cantans Im & . & . & . & . & . & $14^{\mathrm{q}-\mathrm{r}}$ & $22^{r}$ \\
\hline Attendant species & & & & & & & \\
\hline Chorthippus biguttulus Im & $100^{\mathrm{r}-2}$ & $88^{r-2}$ & $89^{r-4}$ & $75^{+-3}$ & $82^{r-2}$ & $57^{r-3}$ & $33^{\mathrm{r}-+}$ \\
\hline Chorthippus biguttulus group $\mathrm{Ny}$ & $100^{1-3}$ & $100^{+-4}$ & $100^{\mathrm{r}-3}$ & $100^{\mathrm{r}-3}$ & $100^{+-4}$ & $95^{\mathrm{r}-5}$ & $78^{+-1}$ \\
\hline Tetrix bipunctata $\mathrm{ssp}$. bipunctata Im & & $13^{\mathrm{q}}$ & $22^{r-+}$ & $13^{+}$ & $27^{\mathrm{r}-+}$ & $14^{+}$ & $11^{+}$ \\
\hline Tetrix bipunctata ssp. krausii Im & & . & $6^{+}$ & & & & $\cdot$ \\
\hline Tetrix bipunctata $\mathrm{Ny}$ & & $13^{\mathrm{q}}$ & $11^{\mathrm{r}-+}$ & & $9^{q}$ & $5^{\mathrm{r}}$ & \\
\hline Stenobothrus stigmaticus Im & & $13^{+}$ & $6^{3}$ & & & & . \\
\hline Stenobothrus stigmaticus $\mathrm{Ny}$ & & $\cdot$ & $6^{3}$ & & . & & \\
\hline Chorthippus albomarginatus Im & & & $6^{+}$ & . & & & $11^{\mathrm{q}}$ \\
\hline Gomphocerippus rufus Im & & & & & & $5^{q}$ & \\
\hline Gomphocerippus rufus $\mathrm{Ny}$ & & . & . & $13^{+}$ & & $5^{q}$ & . \\
\hline Phaneroptera falcata Im & & & & & & $5^{r}$ & \\
\hline Phaneroptera falcata $\mathrm{Ny}$ & & & & & & & $11^{\mathrm{q}}$ \\
\hline Tetrix undulata $\mathrm{Im}$ & & & & & $9^{r}$ & & \\
\hline Tetrix undulata $\mathrm{Ny}$ & & & & & & $\cdot$ & $11^{+}$ \\
\hline Chorthippus brunneus Im & & & & & & $5^{q}$ & . \\
\hline Decticus verrucivorus Im & & & & & & $5^{q}$ & \\
\hline Leptophyes punctatissima Im & . & . & . & . & . & $5^{\mathrm{r}}$ & \\
\hline
\end{tabular}


TABLE 4. Dominance of the Orthoptera species in the structural types. Percentage values, sum of individuals $=$ number of individuals per structural type $=100 \%, 0=$ single specimen $(=0.3 \%$ and/or qualitative detection $), .=$ absence; for further explanation see table 3 and text.

\begin{tabular}{|c|c|c|c|c|c|c|c|}
\hline Structural type & 1 & 2 & 3 & 4 & 5 & 6 & 7 \\
\hline Number of study plots & 5 & 8 & 18 & 8 & 11 & 21 & 9 \\
\hline Sum of individuals & 168 & 245 & 717 & 419 & 577 & 1.353 & 286 \\
\hline \multicolumn{8}{|l|}{ Character and differential species } \\
\hline Myrmeleotettix maculatus & 10 & . & & 0 & & r. & \\
\hline Tetrix tenuicornis & 19 & 5 & 1 & 5 & 0 & 0 & \\
\hline Stenobothrus lineatus & 6 & 18 & 18 & 18 & 12 & 6 & 1 \\
\hline Chorthippus parallelus & & 1 & 2 & 7 & 17 & 21 & 62 \\
\hline Metrioptera brachyptera & & & 0 & 12 & 3 & 18 & 7 \\
\hline Pholidoptera griseoaptera & & 1 & & 2 & 1 & 3 & 4 \\
\hline Omocestus viridulus & & & & & 1 & 3 & 6 \\
\hline Metrioptera roeselii & & & & 0 & & 1 & 9 \\
\hline Tettigonia viridissima & & & & 0 & 1 & 1 & 1 \\
\hline Tettigonia cantans & & & & & & 0 & 1 \\
\hline \multicolumn{8}{|l|}{ Attendant species } \\
\hline Chorthippus biguttulus & 65 & 75 & 68 & 55 & 65 & 47 & 9 \\
\hline Tetrix bipunctata & & 0 & 3 & 1 & 1 & 1 & 1 \\
\hline Stenobothrus stigmaticus & & 1 & 9 & & & $\cdot$ & \\
\hline Chorthippus albomarginatus & & & 1 & . & & & 0 \\
\hline Gomphocerippus rufus & & & & 1 & & 0 & \\
\hline Phaneroptera falcata & & & & & & 0 & 0 \\
\hline Tetrix undulata & & . & & & 0 & . & 1 \\
\hline Chorthippus brunneus & & & & & & 0 & \\
\hline Decticus verrucivorus & & & & & & 0 & \\
\hline Leptophyes punctatissima & & & & & & 0 & \\
\hline
\end{tabular}

is the only one with a high constancy in all structural types.

Structural type 1: Community of gravel-rich calcareous grasslands

The sites have predominantly shallow soils and are south-facing on steep $\left(20-24^{\circ}\right)$ slopes with sparse vegetation (median cover: $40 \%$; Table 3 ). The percentage of both stony surfaces and bare ground are high (median: $30 \%$ ). All plots of this structural type belong to the Gentiano-Koelerietum typicum, gravel-rich subtype. The majority of these sites were sheep grazed.

The occurrence of Myrmeleotettix maculatus is largely restricted to this structural type. Furthermore, Tetrix tenuicornis has a high constancy in the gravel-rich calcareous grasslands, whereas Stenobothrus lineatus regularly occurs in this sparsely vegetated structural type, but at a low density (Table 3).

TABLE 5. Eigenvalues of the first two axes of the Detrended Correspondence Analysis (DCA) and the intraset correlations between DCA axes and the major environmental variables.

\begin{tabular}{lrc}
\hline Axes & 1 & 2 \\
\hline Eigenvalues & 0.63 & 0.31 \\
Sunshine duration & -0.63 & 0.24 \\
Altitude & 0.43 & 0.49 \\
Bare ground and stony surface & -0.67 & 0.00 \\
Cryptogams & 0.25 & -0.35 \\
Shrubs & 0.13 & -0.03 \\
Vegetation density & 0.81 & 0.12 \\
\hline
\end{tabular}

Structural type 2: Community of gap-rich, short-growing semi-dry grasslands

The percentage of bare ground in structural type 2 is still high (median: 18\%, Table 3). Calcareous gravel covers only up to $15 \%$ of the soil surface. Moreover, the turf cover is greater $(55-85 \%)$ than in type 1 . The plots of this structural type belong to the Gentiano-Koelerietum typicum, gravel-rich and gravel-poor subtype and the Gentiano-Koelerietum cladonietosum. All sites are grazed by sheep and goats.

The regional character species of this community are Tetrix tenuicornis (sub-dominant) and Stenobothrus lineatus (dominant) (Table 4). Both species have high constancy values (Table 3 ). Hence, in contrast to structural type 1 , the orthopteran community of this structural type is largely characterized by the absence of $M$. maculatus.

Structural type 3: Community of dense, short-growing semi-dry grasslands

In contrast to the two previous structural types, this one is characterized by a nearly complete coverage of turf (median cover: 90\%). Due to intensive grazing, the sward is still very short (median: $5 \mathrm{~cm}$; Table 3 ). This structural type belongs to the Gentiano-Koelerietum typicum, gravel-poor subtype and the Gentiano-Koelerietum trifolietosum.

Tetrix tenuicornis is quite rare in these swards. However, Chorthippus parallelus is more frequent in this community and differentiates this community from struc- 


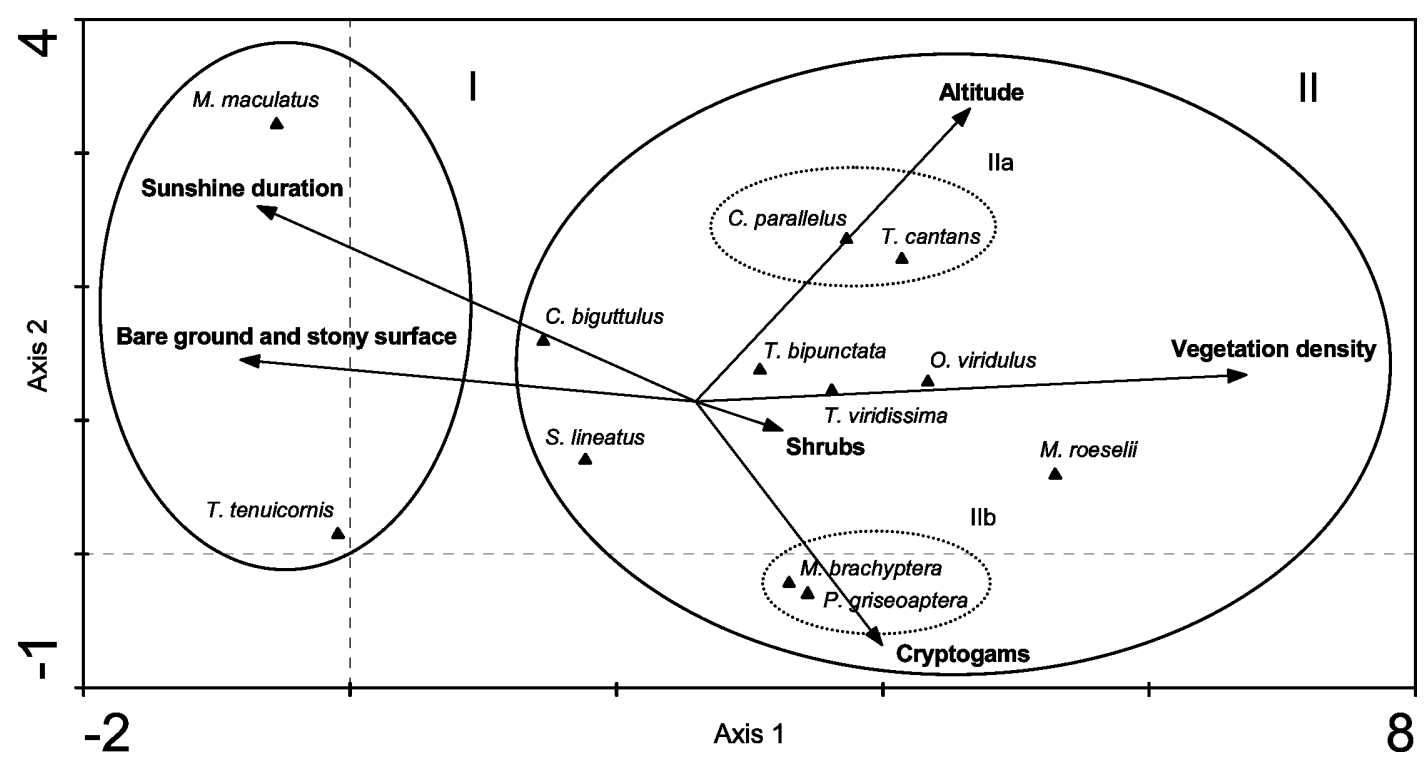

Fig. 3. Detrended Correspondence Analysis (DCA) of the most frequent orthopteran species of the semi-dry calcareous grasslands in the Diemel Valley. The length of the gradient on $1^{\text {st }}$ axis is 4.495 ; the $1^{\text {st }}$ axis explains $21 \%$ and the $1^{\text {st }}$ and $2^{\text {nd }}$ axes $32 \%$ of total variance; the sum of all eigenvalues is 2.978 . For more information see Table 2 and 5 . Species with an absolute constancy $<3$ were excluded from the analysis. Arrows denote major environmental gradients (overlay). Group I: species of bare ground-rich semi-dry grasslands; Group II: species of semi-dry grassland with a high incidence of cover, subgroup IIa: species at high altidudes and subgroup IIb: species of cryptogam-rich semi-dry grassland. Data basis: box quadrat captures (only adults) and environmental parameters of 80 plots; density range: $1-61$ adults $/ 20 \mathrm{~m}^{2}$. The complete orthopteran names are given in Table 3 and 4 .

tural type 2. The only character species is the highly constant Stenobothrus lineatus (Table 3).

Structural type 4: Community of sparse, low-growing semi-dry grasslands

In terms of the horizontal vegetation structure there are similarities with structural type 2 . This structural type has a higher and denser vegetation than type 2 (Table 3). All plots studied of this structural type belong to the Gentiano-Koelerietum typicum, gravel-poor subtype. One half each was sheep grazed and abandoned.

Differences in vertical vegetation structure have an impact on the composition of the orthopteran community: First, phytophilous species such as Metrioptera brachyptera and Chorthippus parallelus, that are absent from structural type 2, reach high constancy values. Second, Tetrix tenuicornis benefits from the abundance of bare ground. Stenobothrus lineatus has very high constancy values and is dominant (18\%) (Table 3 and Table 4).

Structural type 5: Community of dense, low-growing semi-dry grasslands

Compared to the previous type, this type has a higher vegetation cover (median: 95\%). Bare ground is rare (median: 3\%) and there is a more extensive litter layer (median: 25\%). The plant communities making up this structural type are the Gentiano-Koelerietum typicum, gravel-poor subtype and the Gentiano-Koelerietum trifolietosum. All but three sites were grazed sheeply.

Only Chorthippus parallelus, Stenobothrus lineatus and Metrioptera brachyptera could be classified as differential or character species of this structural type (Table 3).
Structural type 6: Community of medium-growing semi-dry grasslands

As in structural type 5, the vegetation cover is nearly complete (median: 95\%). But, as a consequence of the twofold higher field layer (median: $20 \mathrm{~cm}$ ), the vegetation is denser at $10-15 \mathrm{~cm}$ (median: $80 \%$ ) and this type overlaps to the next type. The moss layer has the highest value (median: 50\%). The Gentiano-Koelerietum typicum, gravel-poor subtype with Sesleria facies and the Gentiano-Koelerietum trifolietosum form this structural type. The majority of these sites are abandoned $(N=13)$.

This type is colonised by Chorthippus parallelus and Metrioptera brachyptera as dominant differential and character species, respectively. For the first time, Omocestus viridulus and Pholidoptera griseoaptera have high constancy values whereas the frequency of Stenobothrus lineatus decreases (Table 3 and Table 4 ).

Structural type 7: Community of high-growing semi-dry grasslands

What is characteristic of this structural type is a complete cover of vegetation (median: 100\%) with field layer heights of $25-35 \mathrm{~cm}$. The litter layer reaches its highest values at $95 \%$. The composition of the plant communities in this structural type is very heterogeneous: Brachypodium pinnatum-dominance stands, Gentiano-Koelerietum trifolietosum with crossover to Cynosuretum and Arrhenatheretum, Trifolio-Agrimonietum, respectively. All but two sites have not been managed for years.

Compared to the former type the composition of differential and character species is very different: Stenobothrus lineatus is very rare, two bush-crickets Metrioptera roeselii (constancy: 56\%) and Tettigonia vir- 
idissima (constancy: 33\%) occur more frequently and Chorthippus parallelus is eudominant (Table 3 and Table 4).

\section{Ordination}

The DCA with a gradient-length of 4.495 for the first axis (unimodal model) shows a clear separation of species along the first axis (species-environment correlation: $r=$ 0.907, Table 5), largely falling into two groups (Fig. 3): Taxa that were recorded only on bare ground-rich sites with a high sunshine duration (Myrmeleotettix maculates and Tetrix tenuicornis) and species of sites with denser vegetation (e.g. Metrioptera roeselii and Omocestus viridulus). The second canonical axis is positively correlated with altitude and negatively with cryptogam cover (Fig. 3, Table 5): Some orthopteran species have a strong positive association (in particular Chorthippus parallelus and Tettigonia cantans) and others a negative association (in particular Pholidoptera griseoaptera and Metrioptera brachyptera) with this axis.

\section{DISCUSSION}

\section{Classification of insect communities}

For the classification of insect communities by character and differential species three points are of special importance: (i) the geographical reference area, (ii) the hierarchical level (e.g. habitat complex, habitat and microhabitat) and (iii) clear constancy criteria for the definition of character and differential species. Ecological niches of animal or plant species can vary across latitudinal and altitudinal gradients (Thomas et al., 1998; McPherson \& Jetz, 2007). Hence, the diagnostic character of a species within communities can differ across the range of the species (Kratochwil \& Schwabe, 2001). As a consequence, it is important to mention the biogeographic reference area for which the classification is valid.

Insect communities can be classified at several hierarchical levels. The one chosen depends mainly on the home range of the animals considered. This study deals with two hierarchical levels (habitat and structural type), whereas former studies mostly address only one level (Seitz, 1989; Flade, 1994; Schultz \& Finch, 1997).

Until now, classification of insect communities by character and differential species was mainly intuitive (Seitz, 1989; Flade, 1994; Fartmann, 1997; Schultz \& Finch, 1997; Behrens \& Fartmann, 2004a). Based on Flade (1994) most authors defined character species as species with significantly higher constancy values in one or several units and mostly higher densities than in all other units (Schultz \& Finch, 1997; Kratochwil \& Schwabe, 2001).

The method described in the current paper is the first one that specifies precise constancy criteria for the classification of terrestrial insect communities and is applicable at different hierarchical levels. Since the early 1990s ordination techniques have become more important in orthopteran community analysis (e.g. Kemp et al., 1990; Fielding \& Brusven, 1993; Andersen et al., 2001; Torrusio et al., 2002; Gebeyehu \& Samways, 2003, 2006).
For example functional groups (guilds) can be arranged along ecological gradients (e.g. Szövényi, 2002; Gavlas et al., 2007). In this study, the results of the DCA (Fig. 3) indicate that vegetation structure and the interlinked microclimate strongly accounts for habitat selection in Orthoptera (see also Joern, 1982; Ingrisch \& Köhler, 1998).

For the classification of orthopteran communities we used a method based on constancy criteria because it is (i) more transparent than multivariate techniques and (ii) the habitat requirements of the species can be shown in more detail. Similar approaches have been successfully used in vegetation science for decades (Dierschke, 1994), and continuously improved (Dengler, 2003; Dengler \& Berg, 2004; Schmitt \& Fartmann, 2006). This methodology has the advantage that in addition to the ecological optima the whole niche breadth of a species is revealed, assuming that the sample size is big enough and representative.

\section{Habitat requirements}

Arthropod assemblages in general (Schaffers et al., 2008), and particularly in host-specified insects, like butterflies (Benes et al., 2006), might be best predicted by plant species composition, however, as shown here, orthopteran communities are closely associated with structural types within certain habitats (see also Fartmann, 1997; Morgen, 1998; Behrens \& Fartmann, 2004a). Not only do the stenotopic species (character species) have very specific habitat requirements of special relevance but some eurytopic species have very distinct structural preferences (differential species). Below the habitat requirements of these orthopteran species are discussed (following Table 3 and Fig. 3, see also Poniatowski \& Fartmann, 2006).

Of the character species, Myrmeleotettix maculatus is typical of habitats with little vegetation cover (e.g. Sänger, 1977; Ingrisch, 1984; Zehm, 1997), and a dry and warm microclimate (Detzel, 1998). In the Diemel Valley, the occurrence of $M$. maculatus is restricted to sparsely vegetated Calluna heaths at high altitudes and to calcareous gravel-rich plant communities at low altitudes (Poniatowski \& Fartmann, 2006). In contrast the geophilous Tetrix tenuicornis occurs in several structural types with some bare ground (Schulte, 2003). Occurrence of Stenobothrus lineatus is restricted to semi-natural grasslands in Germany (e.g. Detzel, 1998). In accordance with other studies, S. lineatus prefers low-growing but mostly dense swards within these habitats (Wallaschek, 1995; Behrens \& Fartmann, 2004b). In the Diemel Valley Metrioptera brachyptera is a character species of dwarfshrub-rich upland heath (Poniatowski \& Fartmann, 2007) and semi-dry calcareous grassland (Poniatowski \& Fartmann, 2006). Occurrence of this phytophilous species (Ingrisch \& Köhler, 1998) within the calcareous grasslands is largely restricted to the structural types 4-7, which develop in the absence of grazing (Poniatowski, 2006).

Of the differential species, Chorthippus parallelus colonizes a wide array of habitat types (Ingrisch, 1982) and is one of the most common grasshopper species in 
Germany (Glück \& Ingrisch, 1990). Because of its preferences for the herbaceous layer (Sänger, 1977) and the high moisture requirements of the eggs (Ingrisch, 1983) this species avoids, as in the study area, vegetation-poor sites (Froehlich, 1994; Fartmann, 1997). These sites are too dry and do not fit the vegetation structural requirements of the species (Behrens \& Fartmann, 2004a). The habitat preference of Pholidoptera griseoaptera is one with sufficient hiding places and moisture for the development of its eggs (Ingrisch, 1988). Hence, P. griseoaptera predominantly colonizes abandoned or less intensively used semi-dry calcareous grasslands, often with some shrubs (Morgen, 1998). The medium- to highgrowing herbaceous layer provides a good windbreak in this habitat and reduces the risk of the eggs dehydrating in the soil (Ingrisch, 1988; Detzel, 1998). The mesophilous Omocestus viridulus is typical of calcareous grasslands in regions with an atlantic and subatlantic climate (Ingrisch, 1984). In regions with a low annual precipitation it is restricted to mesic and wet habitats (e.g. Ingrisch, 1981; Fartmann, 1997). The eggs of Metrioptera roeselii are laid in plant stems and are sensitive to desiccation (Ingrisch, 1988). In the semi-dry calcareous grasslands of the Diemel Valley this species is restricted to high-growing and dense swards, which provide the freshmoist microclimate necessary for successful embryonic development (Poniatowski, 2006). Because M. roeselii also colonizes other habitats in the Diemel Valley (e.g. Hill \& Beinlich, 2001) it is a differential species (see Behrens \& Fartmann, 2004a). The sibling species Tettigonia viridissima and $T$. cantans occur allopatrically as they have different habitat requirements in the study area (Poniatowski \& Fartmann, 2006).

Chorthippus biguttulus, the only attendant species with high constancy values, is slightly xerophilous (Glück \& Ingrisch, 1990) and colonizes differently structured types of the semi-dry calcareous grasslands with high constancy (Schulte, 1997). Intermediate and high-growing swards are poorly colonised (Morgen, 1998), presumably because of an adverse microclimate (van Wingerden et al., 1993) and a deficit of egg-laying sites. For egglaying $C$. biguttulus requires bare ground (Ingrisch \& Boekholt, 1983), that is lacking in the structural types 6-7. Because C. biguttulus is also comparatively abundant in these semi-dry calcareous grasslands it is a typical attendant species (Fartmann, 1997; Morgen, 1998; Behrens \& Fartmann, 2004a).

\section{CONCLUSION}

Comparison of the ordination and constancy table (hierarchical classification) indicate that the habitat requirements of the species can be illustrated more condensed and clearly using ordination (Fig. 3). However, the constancy table gives a more detailed insight into the ecology of the species (Table 3 ) and is undispensable for the successful conservation of the species and their habitats (e.g. Hein et al., 2007). Moreover, the hierarchical classification of insect assemblages by defined criteria provides an indication of environmental changes. For a distinct bioge- ographic region and hierarchical level reference communities can be specified (c.f. Cam et al., 2000). Gains and losses of species relative to reference communities can thus be analysed. Inventory completeness (in our case: observed species richness relative to expected richness of the community) is an important criterion in ecology, biogeography and nature conservation (Soberón et al., 2007; Mora et al., 2008) and is nowadays incorporated in conservation policy (e.g. Gómez de Silva \& Medellín, 2001; Greenbaum \& Komar, 2005; Baselga \& Novoa, 2008). But, surveys of typical communities of most regions and habitats of high conservation concern are still lacking (Bernotat et al., 2002). The classification presented is a powerful tool for arthropod conservation, since it allows one to determine the community completeness of very important and threatened habitats, like semi-dry calcareous grasslands. In future, changes in orthopteran species composition due to climate change may require some adjustments in this classification.

ACKNOWLEDGEMENTS. We are very grateful to A.M. Schulte (Meschede) for obtaining information on the distribution of Orthoptera in the Diemel Valley. H. Mattes (University of Münster) was the co-supervisior of the diploma thesis of the first author. For logistic and data support we would like to thank the staff of the Biologische Station Hochsauerlandkreis e.V. (D. Finke, W. Schubert and A.M. Schulte; Schmalenberg-Bödefeld). T. Kleinebecker (University of Münster) helped with statistical problems. We are very grateful to N. Anthes (University of Tübingen), two anonymous reviewers and M. Konvička (Czech Academy of Sciences, České Budějovice, Czech Republic) for valuable comments on the manuscript and to Lillian Harris for improving the English. The Biologische Station Hochsauerlandkreis e.V. and the Akademie für ökologische Landeserforschung e.V. partly funded this study.

\section{REFERENCES}

Andersen A.N., Ludwig J.A., Lowe L.M. \& Rentz D.C.F. 2001: Grasshopper biodiversity and bioindicators in Australian tropical savannas: Responses to disturbance in Kakadu National Park. Austral. Ecol. 26: 213-222.

Anderson R.V., Tracy C.R. \& Abramsky Z. 1979: Habitat selection in two species of short-horned grasshoppers: the role of thermal and hydric stresses. Oecologia 38: 359-374.

BACHER J. 1994: Clusteranalyse - Anwendungsorientierte Einführung. Oldenbourg Verlag, München, 424 pp.

Báldi A. \& KisbenedeK T. 1997: Orthopteran assemblages as indicators of grassland naturalness in Hungary. Agric. Ecosyst. Environ. 66: 121-129.

Baselga A. \& Novoa F. 2008: Coleoptera in a relict forest of Spain: Implications of hyperdiverse taxa for conservation strategies. Ann. Entomol. Soc. Am. 101: 402-410.

Behrens M. \& Fartmann T. 2004a: Die Heuschreckengemeinschaften isolierter Schieferkuppen der Medebacher Bucht (Südwestfalen/Nordhessen). Tuexenia 24: 303-327.

Behrens M. \& FARTMANN T. 2004b: Habitatpräferenzen und Phänologie der Heidegrashüpfer Stenobothrus lineatus, Stenobothrus nigromaculatus und Stenobothrus stigmaticus in der Medebacher Bucht (Südwestfalen/Nordhessen). Articulata 19: 141-165.

BeLlMANN H. 1993: Heuschrecken: beobachten - bestimmen. 3. Naturbuch-Verlag, Augsburg, 349 pp.

Beneš J., Č́̇̌žeK O., Dovala J. \& KonvičKa M. 2006: Intensive game keeping, coppicing and butterflies: The story of 
Milovciky Wood, Czech Republic. Forest Ecol. Manag. 237: 353-365.

Bernotat D., Schlumprecht H., Brauns C., Jebram J., MüllerMotzfeld G., Riecken U., Scheuerlen K. \& Vogel M. 2002: Gelbdruck "Verwendung tierökologischer Daten". In Plachter H., Bernotat D., Müssner R. \& Riecken U. (eds): Entwicklung und Festlegung von Methodenstandards im Naturschutz. Schriftenr. Landschaftspfl. Naturschutz 70: 109-217.

BiERINGER G. \& ZuLKa K.P. 2003: Shading out species richness: edge effect of a pine plantation on the Orthoptera (Tettigoniidae and Acrididae) assemblage of an adjacent dry grassland. Biodivers. Conserv. 12: 1481-1495.

Bruelheide H. 2000: A new measure of fidelity and its application to defining species groups. J. Veg. Sci. 11: 167-178.

Cam E., Nichols J.D., Sauer J.R., Hines J.E. \& Flather C.H. 2000: Relative species richness and community completeness: birds and urbanization in the mid-atlantic states. Ecol. Appl. 10: $1196-1210$.

Chappell M.A. \& Whitman D.W. 1990: Grasshopper thermoregulation. In Chapman R.F. \& Joern A. (eds): Biology of Grasshoppers. Wiley, New York, pp. 143-172.

Chytrý M., TichÝ L., Holt J. \& BotTa-DuKát Z. 2002: Determination of diagnostic species with statistical fidelity measures. J. Veg. Sci. 13: 79-90.

Coray A. \& Lehmann A.W. 1998: Taxonomie der Heuschrecken Deutschlands (Orthoptera): Formale Aspekte der wissenschaftlichen Namen. Articulata 7: 63-152.

Dengler J. 2003: Entwicklung und Bewertung neuer Ansätze in der Pflanzensoziologie unter besonderer Berücksichtigung der Vegetationsklassifikation. Archiv Naturwiss. Diss. 14: 1-297.

Dengler J. \& Berg C. 2004: Vegetationsklassifikation. In Berg C., Dengler J., Abdank A. \& Isermann M. (eds): Die Pflanzengesellschaften Mecklenburg-Vorpommerns und ihre Gefährdung. Textband. Weissdorn-Verlag, Jena, pp. 29-40.

Detzel P. 1998: Die Heuschrecken Baden-Württembergs. Eugen Ulmer, Stuttgart, $580 \mathrm{pp}$.

DierschKe H. 1994: Pflanzensoziologie. Grundlagen und Methoden. Eugen Ulmer, Stuttgart, $683 \mathrm{pp}$.

ENGELMANN H.-D. 1978: Zur Dominanzklassifizierung von Bodenarthropoden. Pedobiologia 18: 378-380.

FARTMANN T. 1997: Biozönologische Untersuchungen zur Heuschreckenfauna auf Magerrasen im Naturpark Märkische Schweiz (Ostbrandenburg). In Mattes H. (ed.): Ökologische Untersuchungen zur Heuschreckenfauna in Brandenburg und Westfalen. Arb. Inst. Landschaftsökol. 3, Münster, pp. 1-62.

FARTMANN T. 2004: Die Schmetterlingsgemeinschaften der Halbtrockenrasen-Komplexe des Diemeltales. Biozönologie von Tagfaltern und Widderchen in einer alten Hudelandschaft. Abh. Westf. Mus. Naturk. 66: 1-256.

FARTMANN T. 2006: Oviposition preferences, adjacency of old woodland and isolation explain the distribution of the Duke of Burgundy butterfly (Hamearis lucina) in calcareous grasslands in central Germany. Ann. Zool. Fenn. 43: 335-347.

Fartmann T., Behrens M. \& Loritz H. 2008: Orthopteran communities in the conifer-broadleaved woodland zone of the Russian Far East. Eur. J. Entomol. 105: 673-680.

Fielding D.J. \& BRusven M.A. 1993: Grasshopper (Orthoptera: Acrididae) community composition and ecological disturbance on southern Idaho rangeland. Environ. Entomol. 22: $71-81$.

FIELDING D.J. \& BRUSVEN M.A. 1995: Ecological correlates between rangeland grasshopper (Orthoptera: Acrididae) and plant communities of Southern Idaho. Environ. Entomol. 24: $1432-1441$.
Flade M. 1994: Die Brutvogelgemeinschaften Mittel- und Norddeutschlands. Grundlagen für den Gebrauch vogelkundlicher Daten in der Landschaftsplanung. IHW, Eching, 879 pp.

Froenlich C. 1994: Analyse der Habitatpräferenzen von Heuschreckenarten (Orthoptera: Saltatoria) in einem Mittelgebirgsraum unter Berücksichtigung regionaler Differenzierungen. Articulata 4: 1-176.

Gardiner T., Hill J. \& Chesmore D. 2005: Review of the methods frequently used to estimate the abundance of Orthoptera in grassland ecosystems. J. Insect Conserv. 9: 151-173.

Gavlas V., Bednár J. \& Krištín A. 2007: A comparative study on orthopteroid assemblages along a moisture gradient in the Western Carpathians. Biologia (Zool.) (Bratislava) 62: 95-102.

Gebeyenu S. \& Samways M.J. 2003: Responses of grasshopper assemblages to long-term grazing management in a semi-arid African savanna. Agric. Ecosyst. Environ. 95: 613-622.

Gebeyehu S. \& Samways M.J. 2006: Topographic heterogeneity plays a crucial role for grasshopper diversity in a southern African megabiodiversity hotspot. Biodivers. Conserv. 15: 231-244.

GLÜCK E. \& INGRISCH S. 1990: Heuschrecken und andere Geradflügler des Federseebeckens. Veröff. Natursch. Landschaftspfl. Bad.-Württ. 64/65[1989]: 289-321.

Gómez de Silva H. \& Medellín R.A. 2001: Evaluating completeness of species lists for conservation and macroecology: a case study of Mexican land birds. Conserv. Biol. 15: 1384-1395.

Greenbaum E. \& Komar O. 2005: Threat assessment and conservation prioritization of the herpetofauna of El Salvador. Biodiv. Conserv. 14: 2377-2395.

Hein S., Binzhöfer B., Poethke H.-J., Biedermann R., Settele J. \& SCHRÖDER B. 2007: The generality of habitat suitability models: A practical test with two insect groups. Basic Appl. Ecol. 8: 310-320.

Hemp A. \& Hemp C. 2000: Die Heuschrecken-Zönosen auf Kalkschutthalden der Nördlichen Frankenalb und ihre Beziehung zur Vegetation. Tuexenia 20: 259-281.

HiLl M.O. 1979: DECORANA - a FORTRAN Program for Detrended Correspondence Analysis and Reciprocal Averagig. Ecology and Systematics, Cornell University, Ithaca, New York, 52 pp.

Hill B.T. \& BeInlich B. 2001: Kommentierte Artenliste der Heuschrecken des Kreises Höxter (Westf.) unter besonderer Berücksichtigung der Sichelschrecke Phaneroptera falcata (Poda, 1761). Egge-Weser 14: 59-68.

Hill M.O. \& Gauch H.G. 1980: Detrended correspondence analysis: an improved ordination technique. Vegetatio $\mathbf{4 2}$ : 47-58.

Horstkotte J., Lorenz C. \& Wendler A. 1994: Heuschrecken. - Bestimmung, Verbreitung, Lebensräume und Gefährdung aller in Deutschland vorkommenden Arten. 12. DJN (Dtsch. Jugendbund f. Naturbeobachtungen), Hamburg, 97 pp.

INGRISCH S. 1977: Beitrag zur Kenntnis der Larvenstadien mitteleuropäischer Laubheuschrecken (Orthoptera: Tettigoniidae). Z. Angew. Zool. (NF) 64: 459-501.

INGRISCH S. 1981: Zur Verbreitung der Orthopteren in Hessen. Mitt. Int. Entomol. Ver. 6: 29-58.

InGRISCH S. 1982: Orthopterengesellschaften in Hessen. Hess. Faun. Briefe 2: 38-46.

INGRISCH S. 1983: Zum Einfluß der Feuchte auf die Schlupfrate und Entwicklungsdauer der Eier mitteleuropäischer Feldheuschrecken (Orthoptera: Acrididae). Dt. Entomol. Z. (NF) 30: $1-15$.

INGRISCH S. 1984: Zur Verbreitung und Vergesellschaftung der Orthopteren in der Nordeifel. Decheniana 137: 79-104. 
INGRISCH S. 1988: Wasseraufnahme und Trockenresistenz der Eier europäischer Laubheuschrecken (Orthoptera: Tettigoniidae). Zool. Jb. Physiol. 92: 117-170.

IngRISCH S. \& Boekholt I. 1983: Zur Wahl des Eiablageplatzes durch mitteleuropäische Saltatoria. Zool. Beitr. (NF) 28: 33-46.

Ingrisch S. \& KöHLER G. 1998: Die Heuschrecken Mitteleuropas. Westarp Wissenschaften, Magdeburg, $460 \mathrm{pp}$.

JoERN A. 1982: Vegetation structure and microhabitat selection in grasshoppers (Orthoptera, Acrididae). Southwest. Natur. 27: 197-209.

JoERN A. 2004: Variation in grasshopper (Acrididae) densities in response to fire frequency and bison grazing in tallgrass prairie. Environ. Entomol. 33: 1617-1625.

JoERn A. 2005: Disturbance by fire frequency and bison grazing modulate grasshopper assemblages in tallgrass prairie. Ecology 86: 861-873.

Jonas J.L. \& Joern A. 2007: Grasshopper (Orthoptera: Acrididae) communities respond to fire, bison grazing and weather in North American tallgrass prairie: a long-term study. Oecologia 153: 699-711.

Jongman R.H., ter BraAK C.F.R. \& VAN TONGEREN O.F.R. 1995: Data Analysis in Community and Landscape Ecology. 2nd ed. Cambridge University Press, Cambridge, 300 pp.

KeMP W.P. 1992a: Temporal variation in rangeland grasshopper (Orthoptera: Acrididae) communities in the steppe region of Montana, USA. Can. Entomol. 124: 437-450.

KemP W.P. 1992b: Rangeland grasshopper (Orthoptera: Acrididae) community structure: A working hypothesis. Environ. Entomol. 21: 461-470.

Kemp W.P., Harvey S.J. \& O’Neill K.M. 1990: Patterns of vegetation and grasshopper community composition. Oecologia 83: 299-308.

Kratochwil A. \& Schwabe A. 2001: Ökologie der Lebensgemeinschaften. Biozönologie. Eugen Ulmer, Stuttgart, 756 pp.

Lockwood A.J. \& Sergeev M.G. 2000: Comparative biogeography of grasshoppers (Orthoptera: Acrididae) in North America and Siberia: Applications to the conservation of biodiversity. J. Insect Conserv. 4: 161-172.

McPherson J.M. \& Jetz W. 2007: Effects of species' ecology on the accuracy of distribution models. Ecography 30: $135-151$.

Mora C., Tittensor D.P. \& Myers R.A. 2008: The completeness of taxonomic inventories for describing the global diversity and distribution of marine fishes. Proc. R. Soc. (B) 275: $149-155$.

MoRgen C. 1998: Ökologische Untersuchungen zur Differenzierung von Heuschreckenzönosen auf Halbtrockenrasen in Plateaulagen im Naturschutzgroßprojekt "Orchideenregion Jena - Muschelkalkhänge im Mittleren Saaletal”. Unpubl. Diploma Thesis, Institute of Landscape Ecology, University of Münster, Münster, $75 \mathrm{pp}$.

Mucina L. 1997: Classification of vegetation: Past, present and future. J. Veg. Sci. 8: 751-760.

MüHLEnBerg M. 1993: Freilandökologie. 3. Quelle \& Meyer, Heidelberg, Wiesbaden, $430 \mathrm{pp}$.

Müller-Temme E. 1986: Niederschläge in raum-zeitlicher Verteilung. Geographisch-landeskundlicher Atlas II, Lieferung 6. Geographische Kommission für Westfalen, Münster, $6 \mathrm{pp}$.

MÜlLER-WILle W. 1981: Westfalen. Landschaftliche Ordnung und Bindung eines Landes. 2. Aschendorfsche Verlagsbuchhandlung, Münster, $411 \mathrm{pp}$.

MURL NRW (Minister für Umwelt, Raumordnung und Landwirtschaft des Landes Nordrhein-Westfalen) (ed.) 1989:
Klima-Atlas von Nordrhein-Westfalen. Selbstverlag (Landesamt f. Agrarordnung), Düsseldorf, $65 \mathrm{pp}$.

Oschmann M. 1969: Bestimmungstabelle für die Larven mitteldeutscher Orthopteren. Dt. Entomol. Z. (NF) 16: 277-291.

OschmanN M. 1973: Untersuchungen zur Biotopbindung der Orthopteren. Faun. Abh. Mus. Tierk. Dresden 4: 177-206.

Poniatowski D. 2006: Die Heuschreckengemeinschaften der Halbtrockenrasen-Komplexe des Diemeltals (Ostwestfalen/ Nordhessen). Mit einem Beitrag zur Ökologie der Kurzflügeligen Beißschrecke (Metrioptera brachyptera). Unpubl. Diploma Thesis, Institute of Landscape Ecology, University of Münster, Münster, 94 pp.

Poniatowski D. \& Fartmann T. 2005: Die Ökologie von Roesels Beißschrecke (Metrioptera roeselii) im Feuchtgrünland der Medebacher Bucht (Südwestfalen). Articulata 20: 85-111.

Poniatowski D. \& Fartmann T. 2006: Die Heuschreckenfauna der Magerrasen-Komplexe des Diemeltals (Ostwestfalen/ Nordhessen). Articulata 21: 1-23.

Poniatowski D. \& Fartmann T. 2007: Kleinräumig heterogen strukturierte Hochheiden in mikroklimatisch günstiger Lage Lebensräume der Kurzflügeligen Beißschrecke (Metrioptera brachyptera) im Quellgebiet der Diemel (Südwestfalen/Nordhessen). Articulata 22: 153-171.

Rennwald E. (ed.) 2002: Verzeichnis und Rote Liste der Pflanzengesellschaften Deutschlands - mit Datenservice auf CDRom. Schriftenr. Vegetat. 35: 1-800.

Samways M.J. 1997: Conservation biology of Orthoptera. In: Gangwere S.K., Muralirangan M.C. \& Muralirangan M. (eds): The Bionomics of Grasshoppers, Katydids and their Kin. CAB International, Wallingford, pp. 481-496.

SÄNGER K. 1977: Über die Beziehungen zwischen Heuschrecken (Orthoptera: Saltatoria) und der Raumstruktur ihrer Habitate. Zool. Jb. Syst. 104: 433-488.

Schaffers A.P., RaEMAKers I.P., SÝKORA K.V. \& ter BraAK C.J.F. 2008: Arthropod assemblages are best predicted by plant species composition. Ecology 89: 782-794.

SCHLUMPRECHT H. 2003: Die Lebensräume der Heuschrecken. In: Schlumprecht H. \& Waeber G. (eds): Heuschrecken in Bayern. Eugen Ulmer, Stuttgart, pp. 306-391.

Schmitt B. \& Fartmann T. 2006: Die Heidenelken-reichen Silikat-Magerrasen der Medebacher Bucht (Südwestfalen/ Nordhessen): Ökologie, Syntaxonomie und Management. Tuexenia 26: 203-221.

SCHULte A.M. 1997: Ökologische Untersuchungen an Heuschrecken auf Magertriften bei Marsberg (Hochsauerlandkreis). In Mattes H. (ed.): Ökologische Untersuchungen zur Heuschreckenfauna in Brandenburg und Westfalen. Arb. Inst. Landschaftsökol. 3, Münster, pp. 97-113.

Schulte A.M. 2003: Taxonomie, Verbreitung und Ökologie von Tetrix bipunctata (Linnaeus 1758) und Tetrix tenuicornis (Sahlberg 1893) (Saltatoria: Tetrigidae). Articulata 10: 1-226. Schultz W. \& Finch O.-D. 1997: Ein TierartenKlassifizierungsverfahren als Basis für biotoptypenbezogene ökofaunistische Zustandsanalysen und Bewertungen. Z. Ökol. Natursch. 6: 151-168.

Sertz B.-J. 1989: Beziehungen zwischen Vogelwelt und Vegetation im Kulturland. Beiheft Veröff. Natursch. Landschaftspfl. Bad.-Württ. 54: 1-236.

SERGEev M.G. 1997: Ecogeographical distribution of Orthoptera. In Gangwere S.K., Muralirangan M.C. \& Muralirangan M. (eds): The Bionomics of Grasshoppers, Katydids, and their Kin. CAB International, Wallingford, pp. 129-146.

Soberón J., JimÉnez R., Golubov J. \& KolefF P. 2007: Assessing completeness of biodiversity databases at different spatial scales. Ecography 30: 152-160. 
Ssymank A., Hauke U., RÜckriem C. \& Schröder E. 1998: Das europäische Schutzgebietssystem NATURA 2000 - BfNHandbuch zur Umsetzung der Fauna-Flora-Habitat-Richtlinie und der Vogelschutz-Richtlinie. Schriftenr. Landschaftspfl. Natursch. 53: 1-560.

Sundermeier A. 1998: Methoden zur Analyse der Vegetationsstruktur. In Traxler A. (ed.): Handbuch des vegetationsökologischen Monitorings. Teil A: Methoden. Umweltbundesamt (Federal Environment Agency), Wien, pp. 123-158.

SZÖVÉNYI G. 2002: Qualification of grassland habitats based on their Orthoptera assemblages in the Közeg Mountains (W-Hungary). Entomol. Exp. Appl. 104: 159-163.

TER BraAk C.F.J. \& Šmilauer P. 2002: CANOCO Reference Manual and CanoDraw for Windows User's Guide: Software for Canonical Community Ordination (version 4.5). Microcomputer Power, Ithaca, New York, 500 pp.

Thomas J.A., Simcox D.J., Wardlaw J.C., Elmes G.W., Hochberg M.E. \& Clarke R.T. 1998: Effects of latitude, altitude and climate on the habitat and conservation of the endangered butterfly Maculinea arion and its Myrmica ant hosts. $J$. Insect Conserv. 2: 39-46.

TonNe F. 1954: Besser bauen mit Besonnungs- und TageslichtPlanung. Karl Hofmann, Schorndorf, 42 pp.

Torrusio S., Cigliano M.M. \& DE Wysiecki M.L. 2002: Grasshopper (Orthoptera: Acridoidea) and plant community relationships in the Argentine pampas. J. Biogeogr. 29: 221-229.
Uvarov B. 1977: Grasshoppers and Locusts. Vol 2. Centre for Overseas Pest Reserch, London, 613 pp.

van SWAay C.A.M. 2002: The importance of calcareous grasslands for butterflies in Europe. Biol. Conserv. 104: 315-318.

van Wingerden W.K.R.E., Bongers W., Cannemeijer F. \& MusTERS J.C.M. 1993: Zum Einfluss der Temperatur auf den Jahreszyklus von Chorthippus biguttulus (Orthoptera: Acrididae) in ungedüngten oder schwach gedüngten Grasflächen. Articulata 8: 61-75.

WALLASCHEK M. 1995: Untersuchungen zur Zoozönologie und Zönotopbindung von Heuschrecken (Saltatoria) im Naturraum "Östliches Harzvorland". Articulata 6: 1-191.

WallisDeVries M.F., Poschlod P. \& Willems J.W. 2002: Challenges fort the conservation of calcareous grasslands in Northwestern Europe: integrating the requirements of flora and fauna. Biol. Conserv. 104: 265-273.

WiLlott S.J. \& Hassall M. 1998: Life-history responses of British grasshoppers (Orthoptera: Acrididae) to temperature change. Funct. Ecol. 12: 232-241.

WisSKIRCHEN R. \& HAEUPLER H. 1998: Standardliste der Farnund Blütenpflanzen Deutschlands. Eugen Ulmer, Stuttgart, $765 \mathrm{pp}$.

Zенм A. 1997: Zur Koinzidenz von Sandvegetation, ihrer Struktur und Heuschrecken-Zönosen (Orthoptera) in der hessischen Oberrheinebene. Tuexenia 17: 193-222.

Received January 31, 2008; revised and accepted May 30, 2008 